\title{
PENGATURAN PELAYANAN ONLINE SINGLE SUBMISSION (OSS) DALAM RANGKA EASE OF DOING BUSINESS DI INDONESIA
}

\author{
I Wayan Wiradarma, Kejaksaan Negeri Rote Ndao, Baa NTT, Email: \\ wiradharma619@gmail.com \\ I Ketut Westra, Fakultas Hukum Universitas Udayana, Email: \\ ketut_westra@unud.ac.id
}

doi : https://doi.org/10.24843/ks.2020.v09.i01.p09

\begin{abstract}
Abstrak
Tujuan penelitian ini adalah untuk menganalisa Penerapan sistem Online Single Submission serta menganalisa Jaminan kepastian hukum bagi pelaku usaha terkait Peraturan Pemerintah No. 24 Tahun 2018 tentang Pelayanan Berusaha Terintegrasi secara Elektronik. Kebijakan baru ini membawa perubahan besar pada iklim investasi sehingga memiliki beberapa hal yang masih dipermasalahkan. Melalui penelitian yang dilakukan secara normatif ini diharapkan dapat memberi pengenalan lebih jauh tentang pendaftaran usaha terbaru dan gambaran pelaksanaannya hingga saat ini. Kebijakan OSS hingga saat ini belum dapat berjalan optimal dikarenakan penyesuaian baik dari Sistem IT yang terintegrasi, peraturan daerah dan pusat terkait penanaman modal, dan lembaga yang berwenang masih dalam transisi untuk mendukung kemudahan berusaha di Indonesia
\end{abstract}

Kata kunci: Online Single Submission, pendaftaran usaha, kemudahan berusaha.

\begin{abstract}
The purpose of this study is to analyze the application of the Online Single Submission system and analyze legal certainty for business actors related to Government Regulation Number 24 of 2018 concerning Electronically Integrated Business Services. This regulation brings huge changes in investment sector hence there are several issues need to be considered. Hopefully, through this normative research, the readers can have deeper understanding about this new policy and the picture of how its implementation until now. This research will describe the reason OSS Policy is not working optimally now. This policy is still needed several adjustment in IT Integrated System, regional dan national regulations concerning investment, and the authority that is responsible to conduct this procedure to enhance ease of doing business in Indonesia.
\end{abstract}

Keywords: Online Single Submission, Register Business, Ease of Doing Business

\section{Pendahuluan}

\subsection{Latar Belakang Masalah}

Berdasarkan indeks yang diterbitkan Bank Dunia tahun 2018 untuk menilai kemudahan berusaha negara-negara, Indonesia berada di peringkat ke-72 Ease of Doing Business (EoDB) pada tahun 2018. ${ }^{1}$ Peringkat ini memang mengalami peningkatan dari

\footnotetext{
${ }^{1}$ Doing Business, Reforming to Create Jobs - World Bank Group, 2018, hlm. 4
} 
ranking ke-91 di tahun 2017 tetapi justru menurun satu tingkat menjadi ke 73 berdasarkan EoDB 2019. Indonesia masih berada di peringkat ke-6 di antara negara ASEAN setelah Malaysia, Thailand, Brunei, dan Vietnam. ${ }^{2}$ Singapura menduduki negara pertama dengan tingkat kemudahan berusaha tertinggi.

Peringkat EoDB Indonesia yang masih tergolong rendah perlu ditingkatkan. Presiden Republik Indonesia, Joko Widodo, dalam nawacitanya memiliki beberapa prioritas pembangunan bidang ekonomi3:

a. Meningkatkan produktivitas rakyat dan daya saing di pasar internasional sehingga bangsa Indonesia bisa maju dan bangkit bersama bangsa-bangsa Asia lainnya;

b. Mewujudkan kemandirian ekonomi dengan menggerakkan sektorsektor strategis ekonomi domestik,

Jika melihat nawacita itu, pembenahan sektor investasi menjadi salah satu solusinya. Dalam dokumen "Capaian 3 Tahun Pemerintahan Joko Widodo-Jusuf Kalla" dari Kantor Staf Presiden, pemerintah menetapkan empat bagian besar yang masuk dalam aspek ini, salah satunya yakni peningkatan investasi.

Sampai saat ini, Pemerintah telah mencabut 9 regulasi dan merevisi 31 regulasi untuk mengurangi bahkan menghilangkan pasal tertentu yang menghambat perekonomian. Selain itu, pemerintah membuat 49 regulasi baru dan menggabungkan 35 regulasi untuk menyederhanakan perizinan dan aturan serta memunculkan 89 regulasi yang mencabut aturan lama agar lebih relevan. Pemerintah juga meluncurkan enam paket kebijakan untuk mendorong pertumbuhan ekonomi dan menaikkan produktivitas, sebagai berikut4:

1. Pusat Logistik Berikat (PLB);

2. Kemudahan berusaha bagi UMKM. Hal ini dilakukan dengan memangkas izin, prosedur, waktu, dan biaya dalam 10 indikator kemudahan berusaha;

3. Revisi Daftar Negatif Investasi. Pasca penerbitan Perpres No. 44/2016, sudah ada 527 perusahaan dengan rencana investasi US\$12.926 miliar yang memanfaatkan;

4. Insentif fiskal. Tax allowance telah dimanfaatkan 25 perusahaan dengan lama pengurusan rata-rata 13,4 hari yang sebelumnya 2 tahun.

5. Perizinan investasi 3 jam. Layanan ini sudah dimanfaatkan 284 perusahaan dengan nilai investasi Rp219 triliun dan serapan tenaga kerja Indonesia 170.657 orang.

6. Pembiayaan ekspor.

Prioritas investasi pada proyek yang berhubungan dengan hajat hidup orang banyak dan memiliki potensi memperkuat pelaku ekonomi nasional diberikan pada pengusaha Indonesia. Sementara, untuk sektor yang belum berkembang dan jarang dimasuki oleh pelaku ekonomi dalam negeri, dibuka hingga 100\% kepada asing. ${ }^{5}$

${ }^{2}$ Perbaikan Pelaksanaan Kemudahan Berusaha Ease of Doing Business di Indonesia-BKPM, www.bkpm.go.id

${ }^{3}$ Inggried Dwi Wedhawary, "Nawa Cita", 9 Agenda Prioritas Jokowi-JK", https://nasional.kompas.com/read/2014/05/21/0754454/.Nawa.Cita.9.Agenda.Prioritas.Jokowi-JK., disarikan dari www.kpu.go.id

${ }^{4}$ Mia Chitra Dinisari, http://finansial.bisnis.com/read/20171020/9/701365/3-tahun-jokowi-jkenam-paket-kebijakan-ekonomi-dan-realisasi-investasi, investasi.html,

5 Meramu Kebijakan Investasi, http://presidenri.go.id/berita-aktual/meramu-kebijakan- 
Agar Indonesia semakin menarik investor asing, salah satu tindakan yang baru - baru ini dilakukan adalah mempermudah proses perizinan berusaha dengan memberlakukan Sistem Online Single Submission (OSS). Sistem ini diberlakukan berdasarkan Peraturan Pemerintah Nomor 24 Tahun 2018 tentang Pelayanan Berusaha Terintegrasi Secara Elektronik (PP No. 24 Tahun 2018) yang juga diamanatkan Perpres Nomor 91 Tahun 2017 tentang Percepatan Pelaksanaan Berusaha.

Pada Pasal 1 Angka 5 PP No. 24 Tahun 2018, OSS didefinisikan sebagai Perizinan Berusaha yang diterbitkan oleh Lembaga OSS untuk dan atas nama menteri, pimpinan lembaga, gubernur, atau bupati/walikota kepada Pelaku Usaha melalui sistem elektronik terintegrasi. Sistem ini berbasis teknologi informasi yang mengintegrasikan perizinan di daerah dan pusat. Sistem OSS merupakan pengembangan Sistem Pelayanan Terpadu Satu Pintu (PTSP) yang sebelumnya berlaku. Sistem ini akan menginterkoneksikan dan mengintegrasikan Sistem Teknologi Informasi dan Komunikasi (TIK) pelayanan perizinanan dengan memanfaatkan PTSP.

Pemberlakuan PP No. 24 Tahun 2018 ini tidak lepas dari berbagai masalah. Penerbitan peraturan pelaksana ini tidak langsung mencabut peraturan daerah yang bertentangan dengan OSS, meskipun ketentuan Pasal 89 yang menghendaki agar menteri/gubernur/bupati/walikota mencabut atau menyatakan tidak berlaku norma, standar, prosedur, kriteria (NPSK) perizinan berusaha yang tidak sesuai dengan PP. Sehingga perlu ditinjau mengenai pembagian tugas antara pusat dan daerah dalam bidang perizinan investasi.

Sistem OSS merupakan sistem yang baru diberlakukan pada bulan Juni tahun 2018. Pemberlakuan sistem ini mengundang pertanyaan mengenai perbedaan proses perizinan berusaha OSS dengan sistem-sistem yang sudah ada sebelumnya seperti PTSP hingga Sisminbakum. Di samping itu, perlu ditinjau lebih lanjut tentang lembaga yang bertugas sebagai pelaksana sistem OSS. Pengetahuan dan pola mikir masyarakat dan pelaku usaha terhadap sistem ini masih kurang sehingga masih menjadi salah satu isu utama yang dihadapi pemerintah. Berbagai macam permasalahan ini perlu dikaji.

Dalam World Investment Report 2017 yang dirilis oleh United Nations Conference on Trade and Development (UNCTAD), Indonesia masuk dalam jajaran 5 besar dengan urutan ke-4 sebagai tempat investasi yang prospektif di dunia. Posisi Indonesia yang berada persis setelah Amerika, China, dan India ini tentu menjadi peringatan bahwa peraturan-peraturan di Indonesia dalam bidang usaha seyogyanya menjamin kepastian hukum sehingga peringkat EoDB Indonesia meningkat sesuai target Pemerintah yaitu peringkat ke-40.

\subsection{Rumusan Masalah}

Berdasarkan hal-hal yang telah diuraikan dalam bagian sebelumnya, penelitian ini akan mencermati permasalahan:

a. Bagaimana penerapan Sistem OSS melalui Peraturan Pemerintah Nomor 24 Tahun 2018 tentang Pelayanan Perizinan Berusaha Terintegrasi secara Elektronik sampai saat ini?

b. Apakah penerapan Peraturan Pemerintah Nomor 24 Tahun 2018 tentang Pelayanan Perizinan Berusaha Terintegrasi secara Elektronik menjamin kepastian hukum bagi pelaku usaha?

\subsection{Tujuan Penelitian}


Penelitian ini dilakukan dengan tujuan untuk melihat keefektivan PP No. 24 Tahun 2018 dalam upaya mempermudah berusaha (Ease of Doing Business) di Indonesia dengan meninjau, mengurai dan menganalisa:

1. Penerapan sistem Online Single Submission melalui PP No. 24 Tahun 2018 tentang Pelayanan Perizinan Berusaha Terintegrasi secara Elektronik hingga saat ini.

2. Jaminan kepastian hukum bagi pelaku usaha semenjak diberlakukannya PP No. 24 Tahun 2018 tentang Pelayanan Perizinan Berusaha Terintegrasi secara Elektronik.

\section{Metode Penelitian}

Penelitian merupakan suatu kegiatan ilmiah yang berkaitan dengan analisa dan konstruksi yang dilakukan secara metodologis, sistematis, dan konsisten. Metodologis berarti sesuai dengan metode atau cara tertentu, sistematis berarti berdasarkan suatu sistem sedangkan konsisten berarti tidak adanya hal-hal yang bertentangan dalam suatu kerangka tertentu. ${ }^{6}$ Penelitian hukum merupakan suatu proses untuk menemukan aturan hukum, prinsip hukum, dan doktrin hukum guna menjawab isu hukum yang dihadapi. Hal ini sesuai dengan karakter perskriptif ilmu hukum. ${ }^{7}$

Ilmu Hukum mempunyai karakteristik sebagai ilmu yang bersifat perskriptif dan terapan. Sebagai ilmu yang bersifat perskriptif, ilmu hukum mempelajari tujuan hukum, validitas aturan hukum, konsep hukum, norma hukum, dan nilai keadilan. Sebagai ilmu terapan, ilmu hukum menetapkan standar prosedur, ketentuan, dan rambu dalam melaksanakan aturan hukum. ${ }^{8}$

Penelitian ini bersifat normatif karena menggunakan bahan-bahan berupa peraturan perundang-undangan dan literatur untuk menganalisa permasalahan yang dirumuskan.

Jenis bahan hukum dalam penelitian ini dapat dikelompokkan sebagai berikut:

a. Bahan hukum primer

Bahan hukum primer merupakan bahan utama yang terkait langsung dengan topik penelitian. Bahan hukum primer yang digunakan dalam penelitian ini, antara lain:

1. Undang-Undang Nomor 25 Tahun 2007 tentang Penanaman Modal;

2. Undang-Undang Nomor 32 Tahun 2004 tentang Pemerintah Daerah;

3. Peraturan Presiden Nomor 91 Tahun 2017 tentang Percepatan Pelaksanaan Berusaha;

4. Peraturan Pemerintah Nomor 24 Tahun 2018 tentang Pelayanan Perizinan Berusaha Terintegrasi Secara Elektronik;

5. Peraturan Kepala BKPM Nomor 14 Tahun 2009 tentang Sistem Pelayanan Informasi dan Perizinan Investasi Secara Elektronik (SPIPISE).

\footnotetext{
${ }^{6}$ Soerjono Soekanto, Pengantar Penelitian Hukum, Jakarta: Penerbit Universitas Indonesia (UIPress), 2007, hlm. 42.

${ }^{7}$ Peter Mahmud Marzuki, Penelitian Hukum, Ed. 1, Cet. 1, Jakarta: Kencana Prenada Media Group, 2007, hlm. 35 .

${ }^{8}$ Ibid.,hlm. 22
} 
6. Peraturan Kepala BKPM Nomor 6 Tahun 2011 tentang Tata Cara Pelaksanaan, Pembinaan, dan Pelaporan Pelayanan Terpadu Satu Pintu Bidang Penanaman Modal;

7. Peraturan Kepala BKPM Nomor 3 Tahun 2012 tentang Pedoman Tata Cara Pengendalian Pelaksanaan Penanaman Modal.

8. Peraturan Kepala BKPM Nomor 5 Tahun 2013 tentang Pedoman dan Tata Cara Perizinan dan Nonperizinan Penanaman Modal.

9. Peraturan Kepala BKPM Nomor 12 Tahun 2013 tentang Perubahan atas Peraturan Kepala BKPM Nomor 5 Tahun 2013 tentang Pedoman dan Tata Cara Perizinan dan Nonperizinan Penanaman Modal.

b. Bahan hukum sekunder

Bahan sekunder yang digunakan dalam penelitian ini berupa informasi terkait topik penelitian seperti buku-buku, jurnal ilmiah, majalah, artikel, tulisan para ahli, maupun tulisan ilmiah lainnya baik yang dimuat dalam media cetak atau elektronik.

c. Bahan hukum tersier

Bahan hukum tersier merupakan bahan yang memberikan penjelasan lebih lanjut mengenai bahan hukum primer dan bahan hukum sekunder yang meliputi kamus, ensiklopedia, indeks kumulatif, dan lain-lain. Dalam penelitian ini, bahan hukum tersier yang digunakan berupa kamus dan indeks kumulatif.

\section{Hasil dan Pembahasan}

Sistem OSS merupakan perbaikan dari Pelayanan Terpadu Satu Pintu. Namun terdapat perbedaan dari kedua hal ini. Deputi Bidang Koordinasi Perniagaan dan Industri Kementerian Koordinator Perekonomian, Eddy Putra Irawady, mengatakan PTSP memiliki sejumlah kelemahan yaitu masih adanya perizinan di tingkat pusat dan di tingkat daerah. Sedangkan dalam sistem OSS, seluruh perizinan mulai dari tingkat pusat hingga daerah menjadi satu kesatuan dan saling mendukung. ${ }^{9}$

Terdapat beberapa hal utama yang belum ada pada PTSP, sebagai berikut ${ }^{10}$ :

a. Adanya satuan tugas (satgas) yang akan mengawal jalannya proses perizinan dari awal hingga akhir;

b. Adanya model registrasi yang lebih modern dan cepat melalui autoregister;

c. Data investor yang sudah terintegrasi bisa digunakan untuk mengurus perizinan lain sehingga investor tidak perlu repot-repot melakukan register ulang saat mengurus perizinan lain;

d. PTSP selama ini menjadi prosedur yang telah memakan banyak waktu. Dengan OSS, proses yang biasanya dilakukan bulanan hingga tahunan dipangkas menjadi hitungan jam. Setiap pelaku usaha (perorangan maupun badan usaha) yang mendaftarkan usahanya melalui Sistem OSS akan mendapatkan NIB (Nomor Induk Berusaha).

9 "Ini Beda Proses Izin Single Submission dan Layanan Satu Pintu", https:/ / dpmptsp.purbalinggakab.go.id/ini-beda-proses-izin-single-submission-dan-layanansatu-pintu/

10 Ibid. 
Pada sistem OSS, Satgas Nasional memiliki tanggung jawab pada pemantauan proses perizinan berusaha dan melaporkannya kepada Presiden. Satgas Provinsi, Kab/Kota menjadi Satgas yang bertanggung jawab terhadap pelayanan perizinan berusaha yang menjadi tanggung jawabnya.

Hingga saat ini, Satgas belum berfungsi secara efektif. Dalam masa transisi ini, maka diperlukan tahapan-tahapan pelaksanaan. Menurut Permenko No 8 Tahun 2017, tugas Satgas Provinsi Tahap 1:

- Melakukan inventarisasi (stock opname) atas seluruh perizinan berusaha yang menjadi kewenangannya dan perizinan yang diperlukan oleh kementerian/lembaga dan pemerintah kabupaten/kota yang telah diajukan dan belum selesai.

- Melakukan penyelesaian hambatan (debottlenecking) atas seluruh perizinan berusaha yang menjadi kewenangannya dan perizinan yang diperlukan oleh kementerian/lembaga dan pemerintah kabupaten/kota yang telah diajukan dan belum selesai.

- Melakukan inventarisasi seluruh perizinan berusaha yang menjadi kewenangannya dan perizinan yang diperlukan oleh kementerian/lembaga dan pemerintah kabupaten/kota.

- Melakukan penyederhanaan proses (debirokratisasi) yang mencakup: penyederhanaan pengajuan dan penyelesaian perizinan, percepatan waktu penyelesaian, dan penggunaan data sharing atas dokumen perizinan yang disampaikan oleh pelaku usaha. Melakukan pelayanan perizinan berusaha yang baru dengan menerapkan penyederhanaan proses (debirokratisasi).

Tugas Satgas Provinsi pada Tahap II:

- Melakukan reformasi peraturan perizinan berusaha pada sektornya:

a) menyusun daftar peraturan yang akan diganti (peraturan daerah dan peraturan/keputusan kepala daerah dan mengusulkan perubahan atas undang-undang, peraturan pemerintah, peraturan presiden, dan/atau keputusan presiden) berdasarkan hasil evaluasi;

b) menyusun rancangan peraturan daerah atau keputusan kepala daerah pengganti peraturan sebelumnya; dan

c) menyusun dan menyampaikan usulan perubahan atas undang-undang, peraturan pemerintah, peraturan presiden, dan/atau keputusan presiden yang menghambat kepada Menteri Koordintor Bidang Perekonomian selaku Ketua Satuan Tugas Nasional Percepatan Pelaksanaan Berusaha.

- Mengidentifikasi kesiapan dukungan teknologi dalam rangka penerapan perizinan melalui infromasi dan teknologi online (Online Single Submission).

- Menyiapkan pembiayaan dan sumber daya dalam rangka penerapan perizinan melalui Online Single Submission.

Sementara itu, Tugas Satgas Kabupaten/Kota pada Tahap I:

- Melakukan inventarisasi (stock opname) atas seluruh perizinan berusaha yang menjadi kewenangannya dan perizinan yang diperlukan oleh 
kementerian/lembaga dan pemerintah provinsi yang telah diajukan dan belum selesai.

- Melakukan penyelesaian hambatan (debottlenecking) atas seluruh perizinan berusaha yang menjadi kewenangannya dan perizinan yang diperlukan oleh kementerian/lembaga dan pemerintah provinsi yang telah diajukan dan belum selesai.

- Melakukan inventarisasi seluruh perizinan berusaha yang menjadi kewenangannya dan perizinan yang diperlukan oleh kementerian/lembaga dan pemerintah provinsi.

- Melakukan penyederhanaan proses (debirokratisasi) yang mencakup: penyederhanaan pengajuan dan penyelesaian perizinan, percepatan waktu penyelesaian, dan penggunaan data sharing atas dokumen perizinan yang disampaikan oleh pelaku usaha.

- Melakukan pelayanan perizinan berusaha yang baru dengan menerapkan penyederhanaan proses (debirokratisasi).

Selain itu, tugas Satgas Kabupaten/Kota pada Tahap II:

- Melakukan reformasi peraturan perizinan berusaha pada sektornya:

a) menyusun daftar peraturan yang akan diganti (peraturan daerah dan peraturan/keputusan kepala daerah dan mengusulkan perubahan atas undang-undang, peraturan pemerintah, peraturan presiden, dan/atau keputusan presiden) berdasarkan hasil evaluasi;

b) menyusun rancangan peraturan daerah atau keputusan kepala daerah pengganti peraturan sebelumnya; dan

c) menyusun dan menyampaikan usulan perubahan atas undang-undang, peraturan pemerintah, peraturan presiden, dan/atau keputusan presiden yang menghambat kepada Menteri Koordintor Bidang Perekonomian selaku Ketua Satuan Tugas Nasional Percepatan Pelaksanaan Berusaha.

d) Mengidentifikasi kesiapan dukungan teknologi dalam rangka penerapan perizinan melalui informasi dan teknologi online (Online Single Submission).

e) Menyiapkan pembiayaan dan sumber daya dalam rangka penerapan perizinan melalui Online Single Submission.

Satgas ini dibentuk untuk meningkatkan pelayanan, pengawalan, penyelesaian hambatan, penyederhanaan, dan pengembangan sistem online sehingga penyelesaian perizinan berusaha dapat berjalan lebih cepat. Permasalahan evaluasu ataupun perbaikan peraturan pusat dan peraturan daerah yang dianggap saling bertentangan masih menjadi tugas Satgas hingga saat ini untuk memperlancar perizinan investasi.

Perubahan prosedur perizinan dari PTSP ke OSS bukan hal yang mudah untuk dilakukan karena memerlukan waktu. Proses ini masih dalam masa peralihan sehingga permasalahan terkait Lembaga OSS, sistem IT, persesuaian peraturan daerah dengan pusat terkait perizinan masih belum mumpuni. Sehingga, efektivitas pelaksanaan sistem OSS sesungguhnya belum dapat dinilai karena belum berjalan sebagaimana yang dirancangkan. 
Menurut Teori Lawrence Friedman, melihat efektivitas suatu sistem hukum atau legal system dapat ditinjau dari tiga unsur yaitu: 11

1) struktur hukum: kerangka yang memberikan perlindungan menyeluruh bagi suatu sistem hukum. Struktur ini terdiri dari elemen-elemen jumlah dan besar badan peradilan, bagaimana peraturan perundangundangannya dan prosedur apa yang harus dilakukan oleh para penegak hukum. Struktur bersifat sebagai pembatas gerakan.

2) substansi hukum: pengertian peraturan yang sesungguhnya, norma, dan tatanan pergaulan masyarakat yang berlaku dalam suatu sistem. Substansi juga mengandung pengertian produk atau keputusan dari pembuat peraturan perundang-undangan.

3) budaya hukum: sikap perilaku masyarakat terhadap hukum dan sistem hukum. Hal ini mencakup bagaimana kepercayaan, nilai, ide, dan pengharapan mereka terhadap hukum. Ide pemikiran ini yang membuat hukum dapat berjalan sebagaimana mestinya.

Kehadiran Sistem OSS yang diberlakukan melalui PP 24 Tahun 2018 mengubah tatanan sistem berusaha yang telah ada sebelumnya. Baik dari sisi struktur hukum, substansi hukum, dan budaya hukum dalam berusaha berubah.

Berdasarkan struktur hukumnya, lembaga yang akan melaksanakan sistem ini adalah lembaga OSS. Namun, kepastian posisi lembaga OSS belum mendapatkan kepastian. Perihal substansi hukum, sebagaimana diuraikan sebelumnya bahwa masih terdapat peraturan-peraturan daerah tentang penanaman modal pada sector tertentu yang belum sejalan dengan tujuan yang ingin dicapai PP 24 Tahun 2010 ini. Sementara itu, baik pelaku usaha,masyarakat dan juga para penyelenggara negara/pegawai negeri yang selama ini bertugas mengurusi perizinan belum memiliki pemahaman dan kemampuan yang seragam untuk menggunakan dan menyempurnakan sistem ini. Berbagai macam perombakan sistem IT, input dokumen, serta koordinasi kepada lembaga atau kementrian lain seperti Kementrian Hukum dan HAM yang selama ini juga mengurus administrasi perizinan badan usaha dan pemerintah daerah harus dilakukan untuk mengintegrasikan sistem perizinan dan dokumen-dokumen yang selama ini tersebar di berbagai lembaga sehingga dapat terakses secara real time. Hal ini menunjukkan bahwa baik budaya hukum penyelenggara sendiri yang selama ini terbiasa dengan prosedur yang berbelit-belit belum siap dengan sistem baru ini.

Berdasarkan uraian tersebut, maka pelaksanaan sistem OSS saat ini belum memberikan kepastian dan keadilan kepada pihak yang berminat untuk membuka usaha di Indonesia. Namun, upaya pemerintah untuk menjadikan Indonesia sebagai negara dengan kemudahan berusaha perlu diapresiasi dan didukung.

\section{Kesimpulan}

Sistem OSS merupakan sistem baru untuk memudahkan pelaku usaha memulai usahanya di Indonesia. Sistem ini merupakan pengembangan dari PTSP yang sebelumnya berlaku. Pelaksanaan sistem ini masih dalam masa peralihan.

${ }^{11}$ Lawrence M. Friedman, Hukum Amerika: Sebuah Pengantar (American Law: An Introduction, $2^{\text {nd }}$ Edition), diterjemahkan oleh Wishnu Basuki (Jakarta: Tatanusa, 2001), hlm. 6-8. 
Dikarenakan proses transisi ini membutuhkan waktu, hingga saat ini baik dari sistem IT, Sumber Daya Manusia (pegawai negeri/penyelenggara negara) yang menjalankan sistem ini serta lembaga OSS, dan peraturan-peraturannya (baik pusat dan daerah) senantiasa disempurnakan di bawah tanggung jawab Satgas yang masih dalam proses pembentukan di seluruh daerah seluruh Indonesia. Namun, penyempurnaan sistem ini tidak menghentikan sistem beroperasi. Apabila meninjau keefektifan dari pelaksanaan sistem ini, maka sistem OSS belum menawarkan kemudahan bagi para pelaku usaha (baik lokal maupun asing) untuk membuka usaha di Indonesia saat ini. Penelitian lebih lanjut setelah sistem ini diberi kesempatan beroperasi selama beberapa tahun perlu dilakukan agar keefektifan sistem ini dapat dinilai lebih akurat.

\section{Daftar Pustaka}

Buku

Erman Rajagukguk, "Peranan Hukum Dalam Pembangunan Pada Era Globalisasi: Implikasinya Bagi Pendidikan Hukum di Indonesia," Pidato Pengukuhan diucapkan pada upacara penerimaan Guru Besar dalam bidang Ilmu Hukum Fakultas Hukum Universitas Indonesia, Jakarta, 4 Januari 1997

Lawrence M. Friednman, Hukum Amerika: Sebuah Pengantar (American Law: An Introduction, $2^{\text {nd }}$ Edition), diterjemahkan oleh Wishnu Basuki (Jakarta: Tatanusa), 2001.

Peter Mahmud Marzuki, Penelitian Hukum, Ed. 1, Cet. 1, Jakarta: Kencana Prenada Media Group, 2007.

Soerjono Soekanto, Pengantar Penelitian Hukum, Jakarta: Penerbit Universitas Indonesia (UI-Press), 2007.

Soerjono Soekanto dan Sri Mahmudji, Penelitian Hukum Normatif Suatu Tinjauan Singkat, (Jakarta: PT. Raja Grafindo Persada), 2011.

Sri Mamudji, et.al. Metode Penelitian Penulisan Hukum, (Jakarta: Badan Penerbit Fakultas Hukum Universitas Indonesia), 2005

Theo Huijbers, Filsafat Hukum, Cetakan ke 15 (Yogyakarta: Kanisius), 2010.

\section{Peraturan Perundang-Undangan}

Indonesia, Undang-Undang Penanaman Modal, UU No. 25 Tahun 2007, LN No. 67

Tahun 2007, TLN No. 4724, Penjelasan Ps. 1 angka 10.

Peraturan Kepala BKPM No. 5 Tahun 2013

\section{Website}

Doing Business 2018-Reforming to Create Jobs - World Bank Group

Perbaikan Pelaksanaan Kemudahan Berusaha Ease of Doing Business di IndonesiaBKPM, www.bkpm.go.id

Inggried Dwi Wedhawary, "Nawa Cita", 9 Agenda Prioritas Jokowi-JK", https://nasional.kompas.com/read/2014/05/21/0754454/.Nawa.Cita.9.Agen da.Prioritas.Jokowi-JK., disarikan dari www.kpu.go.id, 21 Mei 2014.

"Ini Beda Proses Izin Single Submission dan Layanan Satu Pintu", https://dpmptsp.purbalinggakab.go.id/ini-beda-proses-izin-single-

submission-dan-layanan-satu-pintu/ yang diakses pada tanggal 10 Desember 2018 
Mia Chitra Dinisari, http://finansial.bisnis.com/read/20171020/9/701365/3-tahunjokowi-jk-enam-paket-kebijakan-ekonomi-dan-realisasi-investasi,20 $\quad$ Oktober 2017.

Meramu Kebijakan Investasi, http://presidenri.go.id/berita-aktual/meramukebijakan-investasi.html, 7 Mei 2016. 